\title{
Hidden impacts of the Samarco mining waste dam collapse to Brazilian marine fauna - an example from the staurozoans (Cnidaria)
}

\author{
Lucília Souza Miranda ${ }^{1,3}$ \& Antonio Carlos Marques ${ }^{1,2}$ \\ ${ }^{1}$ Universidade de São Paulo, Instituto de Biociências, Departamento de Zoologia, São Paulo, SP, Brazil. \\ ${ }^{2}$ Universidade de São Paulo, Centro de Biologia Marinha, São Sebastião, SP, Brazil. \\ ${ }^{3}$ Corresponding author: Lucília Souza Miranda, e-mail: mirandals@ib.usp.br
}

MIRANDA, L.S., MARQUES, A.C. Hidden impacts of the Samarco mining waste dam collapse to Brazilian marine fauna - an example from the staurozoans (Cnidaria). Biota Neotropica. 16(2): e20160169. http://dx.doi.org/10.1590/1676-0611-BN-2016-0169

\begin{abstract}
The collapse of the Fundão tailings dam at Mariana (State of Minas Gerais, Brazil) started a huge human tragedy and likely the most serious environmental disaster in recent Brazilian history. The dam had contained waste from processing iron ore from mines owned by Samarco, a joint venture company of the Brazilian Vale S.A. and the Anglo-Australian BHP Billiton Ltd. Following ineffective attempts to contain the disaster, after 16 days the mud flood reached the sea, where its impact is expected to affect thousands of marine fauna and flora species. Here, we provide an example of one of these species, the cnidarian Kishinouyea corbini Larson 1980 (Staurozoa), emblematic because it is extremely rare, poorly studied, and its known distribution overlaps the threatened area on the Brazilian coast. Based on this case, we discuss the need for efforts to monitor and minimize the possible impacts of this socio-environmental crime, as well as to identify and punish all responsible players in this tragedy, including negligent licensing and supervisory state agencies, in order to prevent future similar tragedies.
\end{abstract}

Keywords: Espírito Santo, Rio Doce, mud, Staurozoa, Kishinouyea corbini.

MIRANDA, L.S., MARQUES, A.C. Impactos ocultos do colapso da barragem de resíduos da mineradora Samarco para a fauna marinha brasileira - um exemplo em estaurozoários (Cnidaria). Biota Neotropica. 16(2): e20160169. http://dx.doi.org/10.1590/1676-0611-BN-2016-0169

Resumo: O colapso da barragem de rejeitos de Fundão, em Mariana (Minas Gerais, Brasil) iniciou uma enorme tragédia humana e, provavelmente, o mais grave desastre ambiental da história recente do Brasil. A barragem continha rejeitos do processamento de minério de ferro de minas de propriedade da Samarco, uma empresa controlada pela brasileira Vale S.A. e pela anglo-australiana BHP Billiton Ltda. Apesar de tentativas ineficazes para conter o desastre, após 16 dias a lama atingiu o mar, onde provavelmente afetará milhares de espécies da fauna e flora marinhas. Este ponto de vista fornece um exemplo de uma dessas espécies, o cnidário Kishinouyea corbini Larson 1980 (Staurozoa), emblemática pois é extremamente rara, insuficientemente estudada e sua distribuição conhecida para a costa brasileira sobrepõe a área ameaçada pelo desastre. Com base neste caso, discutimos a necessidade de esforços para monitorar e minimizar os possíveis impactos desse crime socioambiental, bem como para identificar e punir todos os responsáveis por esta tragédia, incluindo agências estatais de fiscalização e licenciamento negligentes, a fim de evitar futuras tragédias semelhantes.

Palavras-chave: Espírito Santo, Rio Doce, lama, Staurozoa, Kishinouyea corbini.

On November 5, 2015, the collapse of the Fundão tailings dam near the Rio Doce at Mariana (State of Minas Gerais, Brazil) started a huge human tragedy and likely the most serious environmental disaster in recent Brazilian history. The Fundão retention pond had contained waste from processing iron ore from mines owned by Samarco, a joint venture company of the Brazilian Vale S.A. and the Anglo-Australian BHP Billiton Ltd. Although the consequences of this release of some 50 million cubic meters of mud and toxic sludge are still unfolding, the spill has caused 19 fatalities, buried the subdistrict of Bento Rodrigues, and dislodged numerous families, and its passage downstream has erased the riverine fishery and compromised access to clean water and food for hundreds of thousands of residents in riverside communities.

The environmental damage is also catastrophic. The mud traveled about $650 \mathrm{~km}$ along the Rio Doce Basin, among the most important South-American river basins, causing a massive mortality of its biota, mostly buried and suffocated by the mud. Riverside areas were also affected, and may be exposed to heavy metals and other toxic substances in the muddy waste (according 
to the United Nations Office of the High Commissioner for Human Rights, http://www.ohchr.org/), which are often bioaccumulated in the food chain (Wang 2002), triggering manifold damage to organisms (Bryan 1971).

Following ineffective attempts to contain the disaster, after 16 days the mud flood reached the sea, where its impact is expected to be equally devastating and long-lasting. The regime of ocean currents, winds, and rains is driving the mud tailings southward and northward from the mouth of the Rio Doce, in the State of Espírito Santo (ES), reaching a total area of about $7,000 \mathrm{~km}^{2}$ (January, 2016; including areas with higher and lower concentration of the mud plume, http://www.ibama.gov. br/publicadas, IBAMA - NUGEO/SP). Beaches at Linhares (ES), one of the most affected municipalities, have been closed. According to the Brazilian Institute of Environment and Renewable Natural Resources (IBAMA) and the Chico Mendes Institute for Biodiversity Conservation (ICMBio), the denser mud has already affected the marine protected area of Comboios Biological Reserve, in Regência (ES), and the mud plume has reached two other federal conservation units, the Environmental Protection Area of Costa das Algas and the Wildlife Refuge of Santa Cruz, located in the municipalities of Aracruz, Fundão, and Serra (ES) (http://www.icmbio.gov.br/ portal/). In early January 2016, IBAMA and ICMBio voiced suspicions that the mud could have reached the Marine National Park of Abrolhos, in the Abrolhos Archipelago, State of Bahia (BA), a coral reef region that is among the most biodiverse areas in the South Atlantic Ocean (Werner et al. 2010). ICMBio is concerned by the potential decrease of light incidence over Abrolhos' coral reefs caused by water turbidity, in addition to mud sedimentation over the biota.

It is evident that the marine fauna has already been affected by the tragedy, including critically endangered species in Brazil, such as the Leatherback turtle (Dermochelys coriacea; see http://www.iucnredlist.org/). However, thousands of unknown and poorly studied species are also threatened by the disaster. Indeed, recent estimates indicated that $91 \%$ of species in the ocean still await description (Mora et al. 2011), which dramatically worsens the consequences of marine impacts. In addition, rare species are likely to play critical roles even in diverse ecosystems, being important under future unfavorable conditions, such as habitat degradation and climate change (Mouillot et al. 2013). Here, we provide an example of one of these species, emblematic because it is extremely rare, poorly studied, and its known occurrence overlaps the impacted area on the Brazilian coast.

The cnidarian Kishinouyea corbini Larson 1980 (Figure 1a-c) was the first species of the class Staurozoa recorded for Brazil, exactly from the coast of Espírito Santo (Grohmann et al. 1999). Although these tiny benthic stalked jellyfish live in the intertidal zone, they are cryptic and hard to find, often camouflaged on Sargassum sp. (Figure 1b, Grohmann et al. 1999). The diet of stalked jellyfishes consists basically of small crustaceans, such as copepods and amphipods (Zagal, 2004), but there are no information concerning the trophic relationships (prey and predators) for $K$. corbini from Brazil. Specimens from the Espírito Santo coast are deposited in the zoological collections of Museum of Zoology of the University of São Paulo (MZUSP
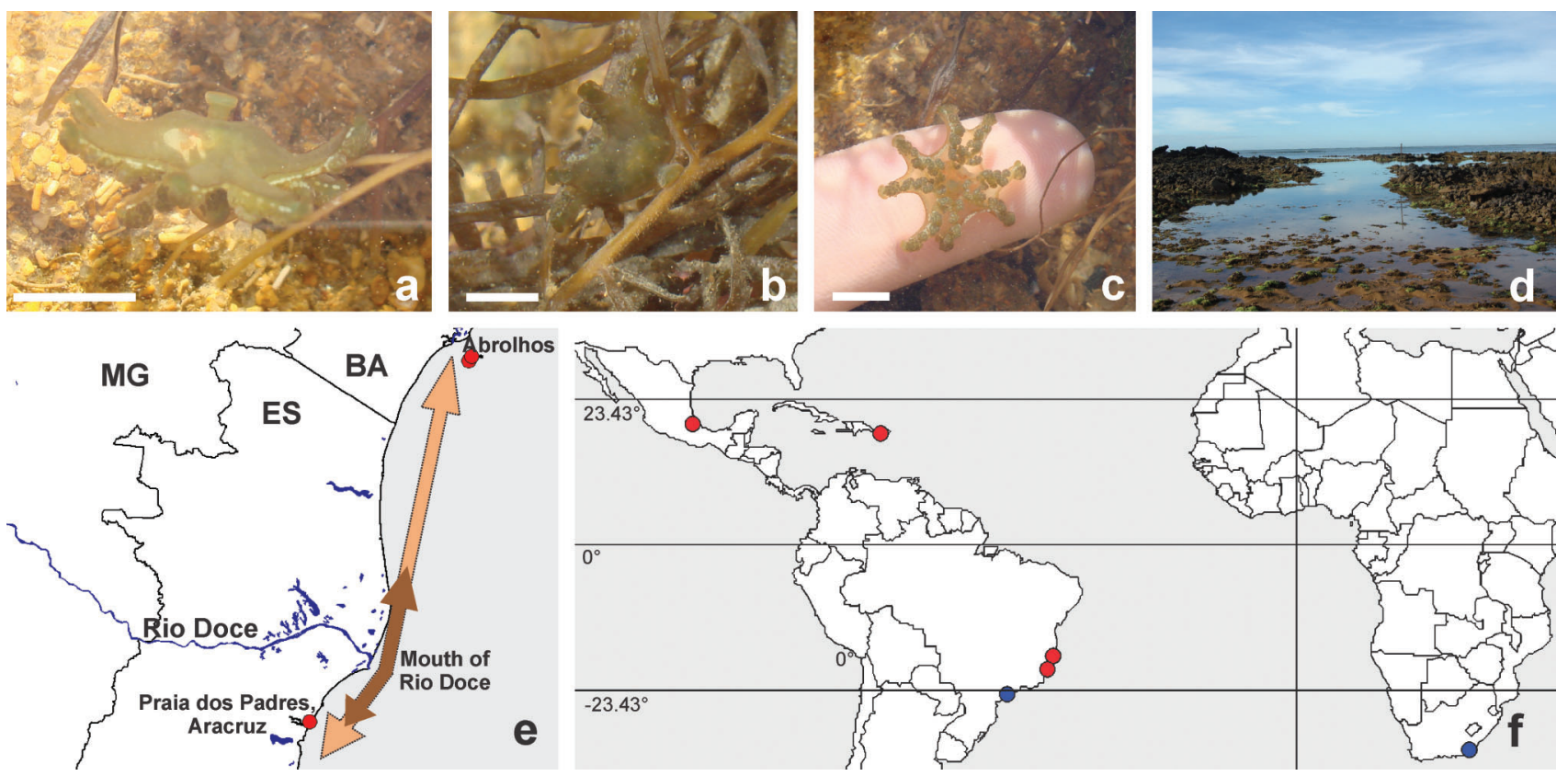

Figure 1. (a) Lateral view of Kishinouyea corbini in the field; (b) Lateral view of K. corbini, attached and camouflaged on Sargassum sp.; (c) Oral view of $K$. corbini on the forefinger of the researcher; (d) Collection site of K. corbini, on Praia dos Padres, Aracruz (ES), during low tide; (e) Area threatened by the mud tailings overlaps the known distribution of $K$. corbini (in red): darker arrows indicate higher concentration of mud and lighter arrows indicate lower concentration of mud plume (Source: IBAMA - NUGEO/SP; January, 2016); (f) Global distribution of K. corbini (in red) and Lucernariopsis capensis (in blue), staurozoan species recorded in Brazil. Photos: A.C. Morandini. Scale: $5.0 \mathrm{~mm}$.

Figura 1. (a) Vista lateral de Kishinouyea corbini no ambiente; (b) Vista lateral de K. corbini, fixa e camuflada no Sargassum sp.; (c) Vista oral K. corbini no dedo indicador do pesquisador; (d) Local de coleta de K. corbini, na Praia dos Padres, Aracruz (ES), durante a maré baixa; (e) Área ameaçada pela lama de rejeitos sobrepõe a área de distribuição conhecida de K. corbini (em vermelho): setas escuras indicam maior concentração de lama e setas claras indicam menor concentração da pluma (Fonte: IBAMA - NUGEO/SP; Janeiro, 2016); (f) Distribuição mundial de K. corbini (em vermelho) e Lucernariopsis capensis (em azul), espécies de Staurozoa registradas para o Brasil. Fotos: A.C. Morandini. Escala: 5,0 mm. 
CNID 1563-1565) and Federal University of Rio de Janeiro (UFRJ-DZ-IB 1-50 to 1-53). There is only one other record of $K$. corbini for the Brazilian coast, in Recife de Viçosa, Abrolhos (BA), whose specimens are deposited in the National Museum of Rio de Janeiro (MNRJ 2472-2473; see Oliveira et al. 2016). However, in fact, the only known established population of the species was located in Praia dos Padres, Aracruz (ES) (Figure 1d, e), an area impacted by the mud plume (Figure 1e). Even though there may be other populations not yet recorded for the species, since $K$. corbini has been also recorded from Puerto Rico (Capriles \& Martínez 1970, Larson 1980) and Mexico (Lechuga \& Alamo 2005) (Figure 1f), the molecular identity of all these materials has never been investigated and the possibility of cryptic species cannot be discarded. We also do not know if these populations are isolated or interdependent, making it difficult to estimate the effect of an impact of this magnitude.

The only other staurozoan known on our coast, Lucernariopsis capensis Carlgren 1938, was recorded only once, at Itanhaém, State of São Paulo (SP) (Figure 1f), in 1985 (Miranda et al. 2012). This fact could be related to the increasing pollution of the southern coast of SP (Miranda et al. 2012), since staurozoan populations seem to be vulnerable to anthropic impacts. For instance, once locally abundant populations of Haliclystus auricula Clark 1863 have now disappeared, probably due to contamination and pollution of their habitat (Mayer 1910, Berrill 1962). This vulnerability is intensified by the relatively low genetic diversity found in populations of Staurozoa (Miranda et al. 2010), in the small number of species that have been intraspecifically investigated.

Staurozoa is a small group of animals, with about 50 species, whose individuals usually live camouflaged on seaweed (Larson 1980, Daly et al. 2007). Most species occur in temperate and polar waters (Mills \& Hirano 2007), and there are only two tropical species, one of them $K$. corbini (Capriles \& Martínez 1970, Larson 1980, Grohmann et al. 1999, Lechuga \& Alamo 2005). Consequently, the impact on the only known population of the species on the Brazilian coast will hamper researches on the group, such as physiological and evolutionary studies about staurozoan adaptations associated with the diversification of the group in warmer waters.

The competent authorities have made only timid efforts to monitor and minimize the possible impacts of this socio-environmental crime, as well as to identify and punish all responsible players in this tragedy, including negligent licensing and supervisory state agencies. Descriptions of the consequences of the disaster will inevitably underestimate the devastating biological reality, since numerous species that are barely studied (including endemic species from the Espírito Santo coast, e.g. the cnidarian Hydrocoryne iemanja Morandini et al. 2009) or even completely unknown occur in the region, such as the example provided above. It is essential to organize and intensify, immediately and effectively, studies of the environmental impacts, and to investigate the responsibilities associated with the environmental licensing process, the lack of a contingency plan, the supervisory failures, and the negligence and even possible deceptive practices of those responsible for authorizing and operating the Fundão dam. The immediate result of a diligent investigation will, at least, increase our ability to prevent future similar tragedies. Most important, the Samarco tragedy should not be seen as an isolated case: it is one of the consequences of the abandonment of environmental values by Brazilian society, with economic development disconnected from conservation/ sustainability and social responsibilities. Sufficiently serious in itself, the microcosm of the Mariana dam is, unfortunately, one small facet of the ingoing environmental catastrophe that is unfolding in the most mega-diverse country in the world.

\section{Acknowledgments}

The authors are grateful to Humberto Y. Yamaguti, André C. Morandini, and Janet Reid for constructive criticisms and help in improving the text. The authors also thank two anonymous reviewers and the Editor Tito Lotufo who helped to improve the quality of the manuscript. This study was supported by FAPESP (2011/50242-5, 2013/50484-4), CNPq (305805/2013-4, 445444/2014-2), and CAPES PNPD.

\section{References}

BERRILL, M. 1962. The biology of three New England stauromedusae, with a description of a new species. Can. J. Zool. 40:1262-1249, http://dx.doi.org/10.1139/z62-101

BRYAN, G.W. 1971. The effects of heavy metals (other than mercury) on marine and estuarine organisms. Proc. Roy. Soc. B 177:389-410, http://dx.doi.org/10.1098/rspb.1971.0037

CAPRILES, V.A. \& MARTÍNEZ, H. 1970. First report of a stauromedusae from Puerto Rico. Caribb. J. Sci. 10:106.

CARLGREN, O. 1938. Eine neue südafrikanische Lucernariidae, Lucernariopsis capensis. Kungl. Fysiografiska Sällskapets i Lund Förhandlingar 8:1-6.

CLARK, H.J. 1863. Prodromus of the history, structure, and physiology of the order Lucernariae. J. Boston Soc. Nat. Hist. 7:531-567.

DALY, M., BRUGLER, M.R., CARTWRIGHT, P., COLLINS, A.G., DAWSON, M.N., FAUTIN, D.G., FRANCE, S.C., MCFADDEN, C.S., OPRESKO, D.M., RODRIGUEZ, E., ROMANO, S.L. \& STAKE, J.L. 2007. The phylum Cnidaria: a review of phylogenetic patterns and diversity 300 years after Linnaeus. Zootaxa 1668:127-182.

GROHMANN, P.A., MAGALHÃES, M.P. \& HIRANO, Y.M. 1999. First record of the order Stauromedusae (Cnidaria, Scyphozoa) from the tropical southwestern Atlantic, with a review of the distribution of Stauromedusae in the southern hemisphere. Species Divers. 4:381-388.

LARSON, R.J. 1980. A new stauromedusa, Kishinouyea corbini (Scyphozoa, Stauromedusae) from the tropical western Atlantic. Bull. Mar. Sci. 30:102-107.

LECHUGA, G.R. \& ALAMO, M.A.F. 2005. Primer registro de Kishinouyea corbini Larson, 1980 (Cnidaria: Scyphozoa, Stauromedusae) para México. Rev. Soc. Mex. Hist. Nat. 7:107-110.

MAYER, A.G. 1910. Medusae of the world. Volume III. Scyphomedusae. Washington, Carnegie Institution Publishing. Publication 109, p. 499-735.

MILLS, C.E. \& HIRANO, Y.M. 2007. Stauromedusae. In Encyclopedia of tidepools and rocky shores (M.W. Denny \& S.D. Gaines, eds). University of California Press, Berkeley, p. 541-543.

MIRANDA, L.S., COLlinS, A.G. \& MARQUES, A.C. 2010. Molecules clarify a cnidarian life cycle - the "hydrozoan" Microhydrula limopsicola is an early life stage of the staurozoan Haliclystus antarcticus. PLoS ONE 5:e10182, http://dx.doi.org/10.1371/ journal.pone.0010182

MIRANDA, L.S., HADDAD, M.A., MILLS, C.E. \& MARQUES, A. C. 2012. Lucernariopsis capensis Carlgren, 1938 (Cnidaria, Staurozoa) in Brazil: first record outside its type locality in South Africa. Zootaxa 3158:60-64.

MORA, C., TITTENSOR, D.P., ADL, S., SIMPSON, A.G.B. \& WORM, B. 2011. How many species are there on earth and in the ocean? PLoS Biol. 9:e1001127, http://dx.doi.org/10.1371/journal. pbio. 1001127

MORANDINI, A.C., STAMPAR, S.N., MIGOTTO, A.E. \& MARQUES, A.C. 2009. Hydrocoryne iemanja (Cnidaria), a new species of Hydrozoa with unusual mode of asexual reproduction. J. Mar. Biol. Ass. U.K. 89:67-76, http://dx.doi.org/10.1017/S0025315408002968 
MIRANDA, L.S. \& MARQUES, A.C.

MOUILLOT, D., BELLWOOD, D.R., BARALOTO, C., CHAVE, J., GALZIN, R., HARMELIN-VIVIEN, M., KULBICKI, M., LAVERGNE, S., LAVOREL, S., MOUQUET, N., PAINE, C.E. T, RENAUD, J. \& THUILLER, W. 2013. Rare species support vulnerable functions in high-diversity ecosystems. PLoS Biol. 11: e1001569, http://dx.doi.org/10.1371/journal.pbio.1001569

OLIVEIRA, O.M.P., MIRANDA, T.P., ADRIANO, E.A, STAMPAR, S.N., KITAHARA, M.V., MENDOZA-BECERRIL, M.A., ARAUJO, E.M., MORANDINI, A.C., BENETI, J.S., CUNHA, A.F., NISHIYAMA, E.Y., SANTOS, M.E.A., MARQUES, A.C., MIRANDA, L.S. \& MIGOTTO, A.E. 2016. Cnidaria in Catálogo taxonômico da fauna do Brasil. PNUD. Available online at: http://fauna.jbrj.gov.br/fauna/faunadobrasil/22 (last access at 25/03/2016)

WANG, W.-X. 2002. Interactions of trace metals and different marine food chains. Mar. Ecol. Prog. Ser. 243:295-309, http://dx.doi.org/ 10.3354/meps 243295

WERNER, T.B., PINTO, L.P., DUTRA, G.F. \& PEREIRA, P.G.P. 2010. Abrolhos 2000: Conserving the southern Atlantic's richest coastal biodiversity into the next century. Coast. Manage. 28:99-108, http://dx.doi.org/10.1080/089207500263684

ZAGAL, C.J. 2004. Diet of stauromedusa Haliclystus auricula from southern Chile. J. Mar. Biol. Ass. U.K. 84:337-340, http://dx.doi.org/ 10.1017/S0025315404009245h

Received 1/02/2016

Revised 26/02/2016

Accepted 10/03/2016 